\title{
Analysis of lead, arsenic and calcium content in the hair of children with autism spectrum disorder
}

\author{
Joanna Fiłon ${ }^{1 *}$, Jolanta Ustymowicz-Farbiszewska² and Elżbieta Krajewska-Kułak
}

\begin{abstract}
Background: Explanation of the pathogenesis and treatment of autism spectrum disorders (ASD) is one of the most significant challenges for scientists today. It is believed that a major pathogenetic factor of this condition is epigenetic changes caused by environmental factors, including toxic metals (cadmium (Cd), lead (Pb), mercury (Hg), aluminium (Al), and arsenic (As)). The nervous system may also be affected by deficiencies of both micro- and macroelements (e.g. calcium (Ca), zinc (Zn)). The aim of the study was to analyze the concentrations of Pb, As, and Ca in the hair of children with ASD and a control group.

Methods: The materials for the study comprised hair samples collected from 30 children diagnosed with ASD (case group) and 30 children randomly selected from the general population of Bialystok and surrounding region (control group). Concentrations of $\mathrm{Pb}, \mathrm{As}$, and Ca were tested with electron microscopy scanning method. Next, the content of the analyzed elements in the hair was assessed as well as their impact on autism development in the children and the mutual interactions between them. The obtained results were statistically analyzed with Statistica PL 12.5., using the Mann-Whitney $U$ test, and Spearman correlation coefficient.
\end{abstract}

Results: Mean Ca level in the hair of the case group was lower than the mean level of this element in the control group. Mean As and Pb concentration in the hair of children with ASD was statistically significantly higher than the mean concentration of this element in the hair of children without neurological disorders. Statistically insignificant weak positive correlations between $\mathrm{Ca}$ and $\mathrm{As}$ content and negative between $\mathrm{Ca}$ and $\mathrm{Pb}$ in the hair of children from the case group were noted. Also, statistically significant mean positive correlations between $\mathrm{Pb}$ and $\mathrm{As}$ were observed.

Conclusions: In this small study, according to the observations, children diagnosed with ASD suffer from Ca deficiency and toxic metal overload ( $\mathrm{As}$ and $\mathrm{Pb}$ ). These abnormalities may play the main role, as an environmental factor, in the pathogenesis of the analyzed disorder.

Keywords: Heavy metals, Lead, Arsenic, Calcium, Children, ASD, Hair

\footnotetext{
*Correspondence: joanna@umb.edu.pl

'Department of Integrated Medical Care, Medical University of Bialystok, Marii

Sklodowskiej-Curie 7A, 15-096 Bialystok, Poland

Full list of author information is available at the end of the article
}

C C The Author(s). 2020 Open Access This article is licensed under a Creative Commons Attribution 4.0 International License, which permits use, sharing, adaptation, distribution and reproduction in any medium or format, as long as you give appropriate credit to the original author(s) and the source, provide a link to the Creative Commons licence, and indicate if changes were made. The images or other third party material in this article are included in the article's Creative Commons licence, unless indicated otherwise in a credit line to the material. If material is not included in the article's Creative Commons licence and your intended use is not permitted by statutory regulation or exceeds the permitted use, you will need to obtain permission directly from the copyright holder. To view a copy of this licence, visit http://creativecommons.org/licenses/by/4.0/ The Creative Commons Public Domain Dedication waiver (http://creativecommons.org/publicdomain/zero/1.0/) applies to the data made available in this article, unless otherwise stated in a credit line to the data. 


\section{Background}

Autism Spectrum Disorder (ASD) is one of the most common neurodevelopmental impairments (in 2014 it was diagnosed in 1 out of 68 children) and is four times more common in boys than girls [1] (https://www.cdc.gov/ ncbddd/autism/data.html). This ratio is higher in those with a mild course of the disorder compared to individuals with an acute course of autism. Over $50 \%$ of children with autism have an intellectual disability, while every third child develops epilepsy and every second child suffers from speech disorders. Apart from intellectual deficits, ASD may also be accompanied by metabolic disorders, motor organ development abnormalities, and chronic somatic diseases [1] (https://www.cdc.gov/ncbddd/autism/ data.html).

In previous years, an increase in the number of diagnosed ASD cases has been observed, which allows to hypothesize that chemical contamination in the environment influences these sorts of developmental disorders [2-4]. Studies indicate the neurotoxic effect of numerous substances, including heavy metals (on mitosis, cell differentiation, synapse formation, oxidative stress, endoplasmic reticulum stress, and essential metalloprotein disruption, apoptotic processes, level of neurotransmitters). Lead $(\mathrm{Pb})$ and arsenic (As) are well-established neurotoxicants known to cross the blood-brain barrier and affect neurodevelopment [1, 5-7]. To give an example, $\mathrm{Pb}$ impairs intellectual development, causes behavioral disorders and motor hyperactivity. It can also have adverse effects on the health of children, causing behavioral and neurological problems, and a reduction in IQ scores $[1,5,6,8-11]$. Similar effects can be observed in the case of As. Arsenic exposure significantly affects brain morphology, resulting in gliosis, neuronal degeneration, a decrease in cognitive abilities, attention, comprehension, language skills, and reduces intelligence quotient (IQ) scores [1, 5, 6, 11-14]. The high levels of heavy metal antagonists (e.g. Ca) in the body act protectively to a certain degree. However, a Ca deficiency can further increase the toxic effect of $\mathrm{Pb}$ and $\mathrm{As}[7,8,15]$.

ASD is a neurodevelopmental disorder, this suggests a possible role of heavy metals in its underlying cause (induction). However, investigations on associations between ASD and neurotoxic heavy metals are inconclusive. Over the last decades, numerous studies have reported a relationship between ASD and $\mathrm{Pb}$ and As exposure [5, 11-13, 16-24]. However, there are also some reports that conclude that heavy metals exposure is not a risk factor for ASD [6, 14, 25-29]. Therefore, an accurate evaluation of the relationship between ASD and heavy metals needs more specific research. This study is the first in Poland and may be an important contribution to the body of knowledge on the subject of metal concentration in the hair of children with ASD.
The aim of the study was to analyze $\mathrm{Pb}, \mathrm{As}$, and $\mathrm{Ca}$ concentrations in the hair of children with ASD and a control group.

\section{Methods \\ Materials}

The materials for the study were hair samples collected from children from an urban agglomeration in Poland. The study group comprised 30 children diagnosed with ASD ( 25 boys and 5 girls) aged from 2 to 8 years (mean age $5.250 \pm 1.586$ years), attending randomly selected therapeutic kindergartens in Bialystok. The control group consisted of 30 neurotypical children ( 25 boys and 5 girls; children who have not been diagnosed with neurological disorders) aged from 2 to 8 years (mean age 5.094 \pm 1.510 years) randomly selected from the general population of Bialystok and the surrounding region.

\section{The procedure of preparing samples and testing element content}

The hair of both groups, ASD cases and control, was taken from 6 different areas of the occipital part of the head. Each hair sample, weighing $0.2-0.5 \mathrm{~g}$, consisted of $3 \mathrm{~cm}$ long sections (cut at the scalp). If hair was longer, only the last $3 \mathrm{~cm}$ from the scalp was examined.

Prior to sample analysis, the hair samples were degreased with chloroform, p.a. grade, three times and next rinsed in redistilled water and dried at $50-60^{\circ} \mathrm{C}$. Further rinsing was performed in a mixture of anhydrous ethanol, p.a. grade, and anhydrous acetone, p.a. grade, mixed in a ratio of 1:1, and then dried at laboratory temperature.

Concentrations of $\mathrm{Pb}$, As, and $\mathrm{Ca}$ were tested with electron scanning microscopy on a Hitachi TM - 3000 apparatus with X-ray microanalyzer EDS.

An assessment of the analyzed element content in the hair, their impact on autism development in children, and dependencies between the concentrations of the analyzed trace elements in the hair was performed.

\section{Quality control}

The accuracy of the method was verified on certified reference material NCS ZC81002 Human Hair (China National Analysis Center). The procedure was analogical to the one applied in testing the analyzed samples. Six tests of the concentration levels of the studied elements in the reference material were performed and the results were compared with the values provided in the certificate.

Standard solutions containing the analyzed elements in proper concentrations had been prepared for each batch. Based on the standard solutions, a calibration chart was compiled for reading the test results. 


\section{Ethics, consent and permissions}

The parents or legal guardians of each child signed a written protocol consent to participate in the study.

The study was approved by the Bioethics Committee of the Medical University of Bialystok (resolution no. R-I-002/18/2015).

\section{Statistical analysis}

The results obtained for each child were averaged and statistically analyzed using StatSoft, Inc. (2014) software STATISTICA (data analysis software system), version 12.5. Statistical analysis of the results included calculating mean values, standard deviation, medians, and the minimum and the maximum of the analyzed elements in the hair. Prior to statistical analysis, an assessment of normal distribution with the Shapiro-Wilk test and the Kolmogorov-Smirnov test was performed. Next, variances of homogeneity were evaluated using the F-test and Levene's test. The distribution of variables differed from normal distribution, therefore the non-parametric Mann-Whitney U test was used. Spearman correlation coefficient (R) was used to evaluate the strength of correlations between the analyzed variables. Statistical significance was considered at $p \leq 0.05$.

\section{Results}

Table 1 presents a comparison of mean levels of concentration, medians, scopes and standard deviations of selected trace elements in the hair of autism spectrum children and those without neurological disorders.

Mean $\mathrm{Ca}$ level in the hair of children with ASD $\left(254.7 \pm 91.96 \mathrm{mg} \mathrm{kg}^{1}\right)$ was lower than the mean level of this element in the control group $\left(312.8 \pm 86.89 \mathrm{mg} \mathrm{kg}^{-1}\right)$ (statistically significant differences, $p=0.002$ ). Mean As concentration in the hair of children with ASD was $0.216 \pm 0.09 \mathrm{mg} \mathrm{kg}^{-1}$ and was statistically significantly higher $(p<0.001)$ than the mean concentration of this element in the hair of children without neurological

Table 1 Levels of particular trace elements in children's hair $\left(\mathrm{mg} \cdot \mathrm{kg}^{-1}\right)$

\begin{tabular}{lllll}
\hline & & Case group $/ n=30$ & Control group $n=30$ & $p$ \\
\hline Ca & M \pm SD & $254.7 \pm 91.96$ & $312.8 \pm 86.89$ & $p=0.002$ \\
& Median & 219.6 & 290.8 & \\
& Range & $149.5-458.1$ & $146.1-543.7$ & \\
As & M SD & $0.216 \pm 0.09$ & $0.061 \pm 0.03$ & $p<0.001$ \\
& Median & 0.196 & 0.058 & \\
& Range & $0.051-0.499$ & $0.004-0.133$ & \\
Pb & M SD & $6.028 \pm 0.69$ & $3.415 \pm 1.207$ & \\
& Median & 5.793 & 3.822 & \\
& Range & $5.178-7.618$ & $0.500-4.490$ & \\
\hline
\end{tabular}

Mann-Whitney $\mathrm{U}$ test was used; $p<0.05$ (statistically significant) $M$ mean, $S D$ standard deviation disorders $\left(0.061 \pm 0.03 \mathrm{mg} \mathrm{kg}^{-1}\right)$. According to observations, mean $\mathrm{Pb}$ concentration in the hair of children with ASD was 2-fold higher compared to mean $\mathrm{Pb}$ concentration in the control group $\left(6.028 \pm 0.69 \mathrm{mg} \mathrm{kg}^{-1}\right.$ and $3.415 \pm 1.207 \mathrm{mg} \mathrm{kg}^{-1}$, respectively) (statistically significant differences, $p<0.001$ ) (Table 1, Fig. 1).

We found weak negative correlations between the levels of the analyzed metals. In the hair of children with ASD $\mathrm{Ca}$ was negatively correlated with $\mathrm{Pb}(r=-0.18$, $p>0.05)$ and positively with As $(r=0.11, p>0.05)$. Statistically significant moderate positive correlations between $\mathrm{Pb}$ and $\mathrm{As}(r=0.36, p<0.05)$ in the hair of children with ASD were observed (Table 2).

\section{Discussion}

There is a list of 201 industrial chemical agents that have a neurotoxic effect on humans (including $\mathrm{Pb}$ and $\mathrm{As}$ ). They may cause autism and other disorders such as attention deficit, mental retardation, and cerebral palsy $[1,16$, 17, 23, 24].

Arsenic (As) is an element that is common in nature and is toxic. It is absorbed into the body primarily through the digestive tract and the respiratory system. In the human body, As compounds may inhibit the activity of over 200 enzymes. The effects of chronic As intoxication include neurotoxic effects in the central and the peripheral nervous system. The symptoms may manifest as sensory changes, muscle sensitivity, sensation of stinging and tingling (paresthesis), weakness, progressing muscle flaccidity, and polyneuropathy with sensory loss. A particularly unfavorable impact is exerted on the central nervous system, and in the case of pregnant women on the development of the fetal nervous system, since it crosses the blood-placenta barrier and accumulates in fetal epithelial tissue in the early stages of pregnancy. In children whose mothers were exposed to As compounds, the following symptoms are observed: difficulty with learning, memory, concentration, cognitive and behavioral disorders. Children exposed to this element may also present the symptoms of retarded development or inhibited physical and mental development $[1,5,6,13$, 23, 29-35].

Lead $(\mathrm{Pb})$ is one of the most dangerous metals due to its common occurrence in the environment. It is highly toxic, has the ability to easily cross biological barriers, and accumulates in the internal organs $[16,17,36] . \mathrm{Pb}$ may affect the functions of both the central and peripheral nervous system as well as the senses. Numerous studies have confirmed that excessive exposure to $\mathrm{Pb}$ results in, among others, convulsions, changes in brain functions, encephalogram changes as well as acute encephalopathy and other brain disorders. In cases when $\mathrm{Pb}$ concentration in the plasma is over $30 \mathrm{mg} \cdot \mathrm{L}^{-1}$, gradual changes in behavior and cognitive functions may 

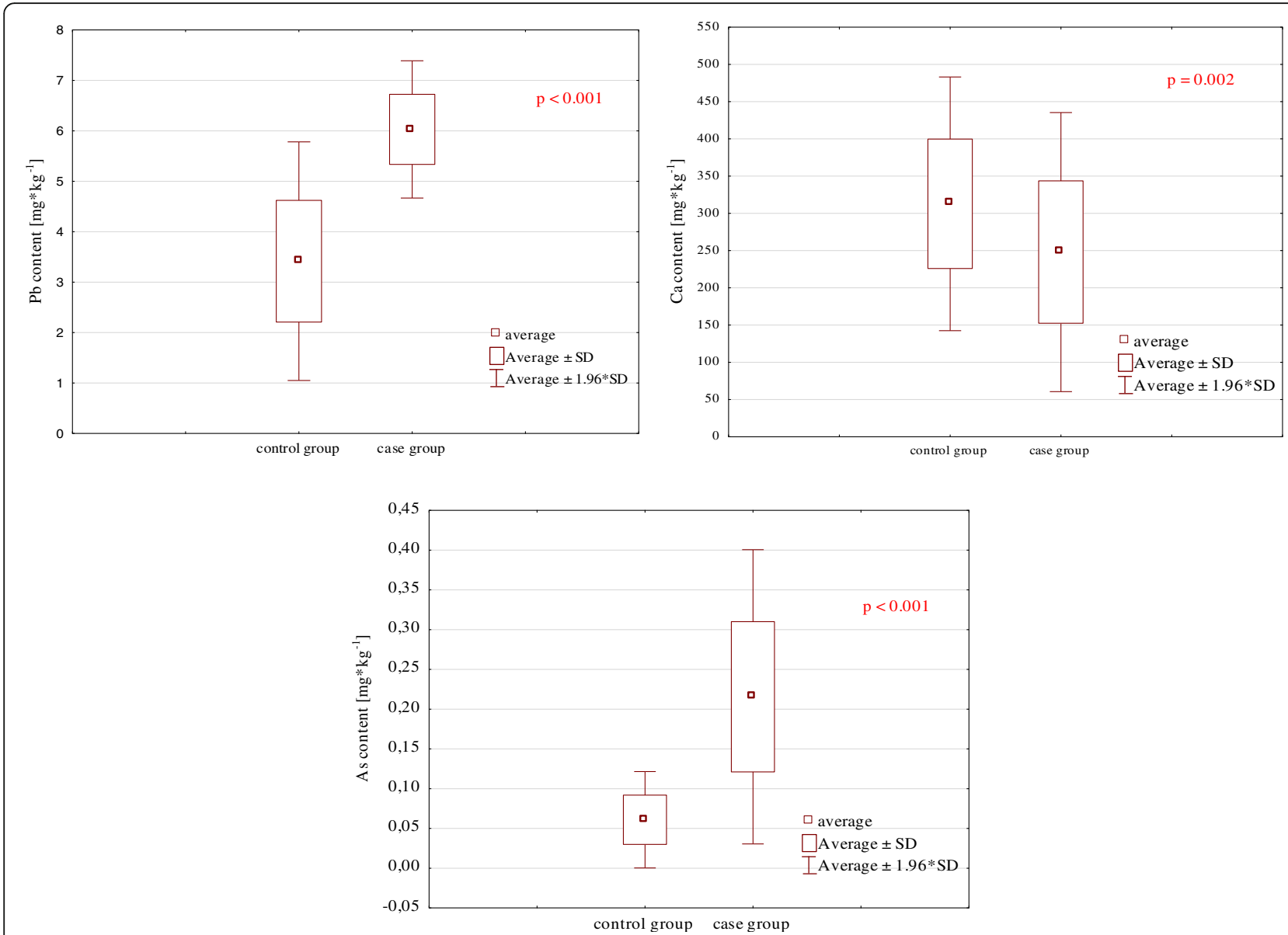

Fig. 1 Relationships between the levels of the studied elements in the hair of ASD cases and the control group $\left(\mathrm{mg} \mathrm{kg}^{-1}\right)$

occur manifesting as irritability, sensory disorders, apathy, impaired visual-motor coordination, and longer time of responding to stimuli $[1,5,6,8,15,22-24,29$, $37-40]$.

The nervous systems of fetuses and small children show higher sensitivity to $\mathrm{Pb}$ intoxication compared to adults. This results from a greater susceptibility of their brains to disorders (especially in the period of fast

Table 2 Correlation between the levels of the studied elements in the hair of the case group and the control group

\begin{tabular}{|c|c|c|c|c|c|c|c|}
\hline & & Case & roup & & Contro & group & \\
\hline & & As & $\mathrm{Ca}$ & $\mathrm{Pb}$ & As & $\mathrm{Ca}$ & $\mathrm{Pb}$ \\
\hline Case group & As & - & 0.11 & $0.36^{*}$ & & & \\
\hline & $\mathrm{Ca}$ & 0.11 & - & -0.18 & & & \\
\hline & $\mathrm{Pb}$ & $0.36^{*}$ & -0.18 & - & & & \\
\hline Control group & As & & & & - & -0.22 & -0.08 \\
\hline & $\mathrm{Ca}$ & & & & -0.22 & - & -0.15 \\
\hline & $\mathrm{Pb}$ & & & & -0.08 & -0.15 & - \\
\hline
\end{tabular}

Spearman correlation coefficient was used * statistically significant $(p<0.05)$ growth). Functional changes of the brain develop in children at over $10 \mathrm{mg} \mathrm{Pb} / 10^{-1} \mathrm{~L}$ of blood causing most of all decreased IQ. Also, $\mathrm{Pb}$ in children leads to disorders of cognitive functions, difficulty learning (mostly reading, learning languages, and mathematics), lack of concentration, impairment of a short-time memory, recurring epileptic seizures, irritability, hyperactivity as well as impairment of speech, vision and even personality (e.g. aggression) [6, 15, 31, 32, 37-42].

In our research, mean $\mathrm{As}$ and $\mathrm{Pb}$ content in the hair of children with ASD was statistically significantly higher compared to the mean content of these elements in the hair of children from the control group (Table 1, Fig. 1). Numerous studies have confirmed that heavy metals play a crucial role in the development of autism spectrum disorders $[1,5,11-13,16-22,24]$. Yasuda et al. $[16,17]$ demonstrated increased $\mathrm{Pb}$ concentrations in $4.8 \%$ of children with ASD and As in $2.6 \%$ (maximal $\mathrm{Pb}$ concentration amounted to $24.9 \mathrm{ppm}$, while As 1.7 ppm). Fido and Al-Saad [25] also observed a significantly higher $\mathrm{Pb}$ concentration in 4-7 year old children with autism compared to normal individuals (6.75 vs 3.20 
$\left.\mathrm{mg} \cdot \mathrm{kg}^{-1}\right)$. Similar $\mathrm{Pb}$ and As content were found in the hair of ASD children from different parts of the world, Saudi Arabia [11, 12, 18, 43], Kuwait [25], Oman [19], India [20], Egypt [21, 22], Italy [26], and the USA [5, 29, 44].

A study conducted on a large group of Mexican children showed a positive correlation between $\mathrm{Pb}$ concentration in the blood and increased severity of overactivity symptoms. $\mathrm{Pb}$ content showed no correlation with attention disorder, which is characteristic of full blown ADHD (attention-deficit hyperactivity disorder) [45]. Meta-analysis of 33 studies published in the years 1972-2010 conducted on 10,232 children showed a positive dependency between $\mathrm{Pb}$ concentration in the blood and hair and overactivity and attention disorders [41]. According to observations, low $\mathrm{Pb}$ concentration in the blood $\left(<3.4 \mathrm{mg} \cdot \mathrm{L}^{-1}\right)$ may be a factor that additionally increases the risk of genetically conditioned ADHD. It was demonstrated that exposure to $\mathrm{Pb}$ causes cognitive deficits similar to those observed in ADHD children as well as impaired attention and cognitive function. Also, studies conducted on children indicated that $\mathrm{Pb}$ impairs the processes of inhibiting response and attention in school-age children. It has also been proven that in the case of blood $\mathrm{Pb}$ concentration $>2.0 \mathrm{mg} \cdot \mathrm{L}^{-1}$ the risk of developing ADHD increases over four times [46].

Numerous clinical control studies have proven increased levels of one or more toxic metals in urine, blood, hair, nails, teeth, and brain samples in autism spectrum children compared to children showing normal development [24, 47]. Al-Ayadhi [18] and BlaurockBusch et al. [11, 12] observed significantly higher concentrations of heavy metals $(\mathrm{Pb}$ and $\mathrm{As}$ ) in the hair of children with ASD compared to healthy children. Adams et al. [27, 47] also demonstrated that children with autism had higher $\mathrm{Pb}$ and As concentrations in urine (by 72 and $21 \%$, respectively) and in the hair (by 30 and $20 \%$, respectively) compared to healthy children.

There is increasing evidence that children with ASD have a considerable disability to process and eliminate toxins from the body $[1,5,6,14,43]$. Toxin accumulation leads to increased activity of free radicals in the body, which in turn affects the structure of the nervous system. It is worth noticing that detoxification and eliminating heavy metals involves their conjugation with glutathione, whose concentrations are considerably lower in ASD individuals [19].

Modern people's exposure to the risk is complex. $\mathrm{Mu}$ tual interactions may occur between particular elements. Toxic metals affect trace element absorption, while the interaction between essential elements and toxic metals affects threshold values and toxicity effects. Toxic metals may interact metabolically with nutritionally essential metals [11, 12, 18]. Resorption of some ions $\left(\mathrm{Ca}^{2+}\right.$, $\mathrm{Mg}^{2+}, \mathrm{Fe}^{2+}, \mathrm{Zn}^{2+}$ or $\mathrm{Cu}^{2+}$ ) from the digestive tract is inhibited by $\mathrm{Pb}$, which is indicative of absorption competitiveness of these elements in the intestines. Also, $\mathrm{Pb}$ impairs the metabolism of minerals and causes multisystemic toxic effects through the inactivation of many enzymes (it binds to sulfhydryl, carboxyl and amino groups of aminoacids and proteins), leads to impaired effects of vital cations $(\mathrm{Ca}, \mathrm{Zn}$ and iron $(\mathrm{Fe}))$, abnormal oxidationreductive condition of cells, impaired structure of cellular membrane and receptor functions. Increased $\mathrm{Pb}$ content enhances $\mathrm{Ca}$ elimination, while decreased $\mathrm{Ca}$ content in the diet causes a higher accumulation of this metal, especially in bones $[8,15,38,39]$. A Ca deficiency may additionally strengthen the toxic effects of $\mathrm{Pb}$ and affect cognitive and behavioral development in children. A significant converse dependency between $\mathrm{Ca}$ intake with diet and $\mathrm{Pb}$ concentration in the blood was observed as early as in the 1990s in 3000 American children in the NHANES II study [7].

According to our research, we found weak negative correlations between the levels of the analyzed metals. In the hair of children with ASD, Ca was negatively correlated with $\mathrm{Pb}$ and positively with As. Statistically significant moderate positive correlations between $\mathrm{Pb}$ and $\mathrm{As}$ in the hair of children with ASD were observed (Table 2). The antagonistic effects of toxic metals and bioelements have been confirmed by a number of studies $[10-12,16,18,20$, 27, 47-50]. The mechanism through which Ca impairs As absorption and conversely has not been fully understood so far. $\mathrm{Ca}$ is able to participate in the inhibition and absorption of As through competitiveness connected with a common binding site with proteins in the intestines [16, $17,33,47]$. Heavy metals, e.g. $\mathrm{Pb}$ and As, have a very similar toxic effect, which in turns leads to the increased severity of intoxication symptoms with concurrent exposure to more than one metal $[1,5,6,24,33]$.

$\mathrm{Ca}$ is a mineral necessary for the normal functioning of the whole body. It regulates the nervous system by improving the transmission of nerve impulses (it is a transmitter of arousal states in nerve synapses). Low concentrations of $\mathrm{Ca}$ in the body cause the following symptoms: irritability and excitability, nervousness, oversensitivity and anxiety states. Chronic Ca deficiency in children may lead to mental disorders $[7,51]$.

In our study, mean Ca content in the hair of children in the ASD case group was lower than the mean content of this element in the control group (statistically significant differences) (Table 1, Fig. 1). Many authors have also observed significantly lower $\mathrm{Ca}$ content in children with autism compared to healthy children. This suggests that children with ASD are susceptible to Ca deficiency [16-18]. The presented results have been reflected in studies by Japanese researchers who noticed a Ca deficiency in approximately $6 \%$ of children. A considerable deficiency of this element has been diagnosed mainly in 
children under 10 years old. The minimal Ca concentration in this group amounted to approximately $70 \mathrm{ppm}$ $[16,17]$. Apart from Ca deficiency, many children with autism also had a deficiency of other elements, including $\mathrm{Zn}, \mathrm{Mg}, \mathrm{Mn}$ or $\mathrm{Cu}[12,16,17,19,49]$. It was also demonstrated that children with autism had significantly lower Ca content in the hair (by 20\%) compared to normal children [27].

Despite a number of studies and analyses, autism is still not understood by scientists, because no specific factor causing this condition has been found. Each experiment provides new valuable data but fails to deliver an explanation for symptom occurrence.

\section{Limitations}

In this study there are several limitations that could be solved in future studies. The main limitation of our work is the small number of cases and the strong regional focus of this study. Samples were taken only from one mid-size city in Poland in a region with rather low pollution levels. The narrow group of only 30 cases of diagnosed children is also too population-specific and probably is not representative of neurodevelopmental disorders in the whole country. The limited number of cases also does not provide adequate statistical confidence. But our work is the first (of its kind) in Poland and hopefully could be the basis for future studies that will have greater (country) range and contribute to the global picture of ASD.

Secondly, there is a very limited number of studies in Europe on the subject of metal concentration in the hair of children with ASD. In the case of research into relationships between metals content in the hair and neurodevelopment disorders, tests should be carried out within larger social groups (preferably international) to avoid falsifying the results through any local influence.

Thirdly, the study did not plan to collect other data on the study subjects. The influence of sociodemographic and environmental factors (medical history, metabolic abnormalities, diet, environmental contamination) on the content of these metals in the hair was also not taken into account. The research results lack information about the exposure of mothers before pregnancy and during pregnancy as well as infants / children at a very early age.

Fourthly, cosmetic procedures have a significant impact on the content of elements determined in the hair. In our research, we did not include the types of cosmetics (e. g. shampoos) used by the children. We only assumed that the examined group consisted of rather small children so they probably use only basic hygiene products, which is not necessarily true. Thus, future studies should consider the relationship between children's cosmetics and contamination in hair.
Fifthly, there are no generally applicable standards for the content of trace elements in the hair of any people (healthy or with any diseases).

Our results are informative, add to the literature, and might make a contribution to the body of knowledge on the subject of trace elements in ASD. More research is needed about the relationships between ASD and heavy metals exposure. Explanation of the pathogenesis and treatment of neurological disorders is one of the greatest challenges for scientists today.

\section{Conclusions}

1. In this small study statistically significantly higher As and $\mathrm{Pb}$ content in the hair of children with ASD compared with the control group was observed.

2. Decreased Ca content in the hair of the case group children compared with the control group was demonstrated.

3. Notwithstanding evident limitations, the study suggests that abnormal concentrations of the analyzed elements may indicate a pathophysiological role of heavy metals and trace elements in the genesis of symptoms of autism spectrum disorders.

\section{Abbreviations}

ADHD: Attention-Deficit Hyperactivity Disorder; Al: Aluminium; As: Arsenic; ASD: Autism Spectrum Disorder; Ca: Calcium; Cd: Cadmium; Fe: Iron; Hg: Mercury; M: Mean; Mg: Magnesium; Mn: Manganese; Pb: Lead; SD: Standard deviation; Zn: Zinc

\section{Acknowledgments}

We would like to thank all teachers and therapists who helped us in researches. We would also like to acknowledge the support provided by Jan Karczewski during determination of trace elements.

\section{Authors' contributions}

All authors developed the research question. JF, JUF designed the study, collected and analyzed data, interpreted the results, wrote the article. JF performed the statistical analyses. EKK coordinated the project, participated in the discussions about the design and interpretation of results, provided meritorical support and constructive comments. All authors read and approved the final manuscript.

\section{Funding}

The study was supported by the Medical University of Bialystok (Project No. $\mathrm{N} / \mathrm{ST} / \mathrm{ZB} / 18 / 009 / 3310)$. This funding institution cover works expenses related to investigative activities including data collection, analysis, interpretation, and publication

\section{Availability of data and materials}

The data and material are available upon reasonable request from the corresponding author. E-mail: joanna@umb.edu.pl

\section{Ethics approval and consent to participate}

Written informed consent was obtained from all parents or legal guardians of the child.

The study was approved by Bioethics Committee of the Medical University of Bialystok, act no: R-I-002/18/2015. 


\section{Competing interests}

The authors declare that they have no competing interests.

\section{Author details}

'Department of Integrated Medical Care, Medical University of Bialystok, Mari Sklodowskiej-Curie 7A, 15-096 Bialystok, Poland. ${ }^{2}$ Department of Hygiene, Epidemiology and Ergonomics, Medical University of Bialystok, 15-089 Bialystok, Poland.

\section{Received: 30 November 2018 Accepted: 10 March 2020} Published online: 23 March 2020

\section{References}

1. Bjørklund G, Skalny AV, Rahman MM, Dadar M, Yassa HA, Aaseth J, Skalnaya MG, Tinkov AA. Toxic metal (loid)-based pollutants and their possible role in autism spectrum disorder. Environ Res. 2018;166:234-50.

2. Bobkowicz-Lewartowska L. Children's autism: issues of diagnosis and therapy. Kraków: Oficyna Wydawnicza Impuls; 2011. (In Polish).

3. Schofield K. The metal neurotoxins: an important role in current human neural epidemics? Int J Environ Res Public Health. 2017;14:1511. https://doi. org/10.3390/ijerph14121511.

4. Deisher TA, Doan NV, Omaiye A, Koyama K, Bwabye S. Impact of environmental factors on the prevalence of autistic disorder after 1979. J Public Health Epidemiol. 2014;6(9):271-84.

5. Dickerson AS, Rahbar MH, Han I, Bakian AV, Bilder DA, Harrington RA, et al. Autism spectrum disorder prevalence and proximity to industrial facilities releasing arsenic, lead or mercury. Sci Total Environ. 2015;1(536):245-51.

6. Li H, Li H, Li Y, Liu Y, Zhao Z. Blood mercury, arsenic, cadmium, and lead in children with autism spectrum disorder. Biol Trace Elem Res. 2018;181(1):317. https://doi.org/10.1007/s12011-017-1002-6.

7. Mahaffey KR, Gartside PS, Glueck CJ. Blood lead levels and dietary calcium intake in 1 to 11 year-old children: the second national health and nutrition examination survey, 1976 to 1980. Pediatrics. 1986;78(2):257-62.

8. Manahan SE. Toxicological Chemistry and Biochemistry. 3rd ed. Boca Raton: CRC Press, Limited Liability Company (LLC); 2003.

9. Kubota T, Mochizuki K, et al. Int J Environ Res Public Health. 2016;13(5):504 https://doi.org/10.3390/ijerph13050504.

10. Schetter T. Developmental disabilities - impairment of Childrens brain development and function: the role of environmental factors. Environ Health Perspect. 2001;109(6):813-6.

11. Blaurock-Busch $\mathrm{E}$, Amin OR, Rabah T. Heavy metals and trace elements in hair and urine of a sample of Arab children with autistic spectrum disorder. Maedica (Buchar). 2011;6(4):247-57.

12. Blaurock-Busch E, Amin OR, Dessoki HH, Rabah T. Toxic metals and essential elements in hair and severity of symptoms among children with autism. Maedica (Buchar). 2012;7:38-48.

13. Zhai $\mathrm{Q}$, Cen S, Jiang J, Zhao J, Zhang $\mathrm{H}$, Chen W. Disturbance of trace element and gut microbiota profiles as indicators of autism spectrum disorder: a pilot study of Chinese children. Environ Res. 2019;171:501-9.

14. Skalny AV, Simashkova NV, Klyushnik TP, Grabeklis AR, Bjorklund G, Skalnaya MG, Nikonorov AA, Tinkov AA. Hair toxic and essential trace elements in children with autism spectrum disorder. Metab Brain Dis. 2017;32(1):195-202.

15. Järup L. Hazards of heavy metal contamination. Br Med Bull. 2003;68:167-82. https://doi.org/10.1093/bmb/ldg032.

16. Yasuda H, Yasuda Y, Tsutsui T. Estimation of autistic children by metallomics analysis. Sci Rep. 2013;3:1199. https://doi.org/10.1038/srep01199.

17. Yasuda $H$, Tsutsui $T$. Assessment of infantile mineral imbalances in autism Spectrum disorders (ASDs). Int J Environ Res Public Health. 2013;10(11): 6027-43. https://doi.org/10.3390/ijerph10116027.

18. Al-Ayadhi LY. Heavy metals and trace elements in hair samples of autistic children in Central Saudi Arabia. Neurosciences. 2005;10(3):213-8.

19. Al-Farsi YM, Waly Ml, Al-Sharbati MM, Al-Shafaee MA, Al-Farsi OA, Al-Khaduri MM, et al. Levels of heavy metals and essential minerals in hair samples of children with autism in Oman: a case-control study. Biol Trace Elem Res. 2012;151(2):181-6. https://doi.org/10.1007/s12011-012-9553-z.

20. Lakshmi Priya MD, Geetha A. Level of trace elements (copper, zinc, magnesium and selenium) and toxic elements (Lead and mercury) in the hair and nail of children with autism. Biol Trace Elem Res. 2011;142(2):14858. https://doi.org/10.1007/s12011-010-8766-2.
21. Elsheshtawy E, Tobar S, Sherra K, Atallah S, Elkasaby R. Study of some biomarkers in hair of children with autism. MECPsych. 2011;18:6-10. https:// doi.org/10.1097/01.XME.0000392842.64112.64.

22. Mohamed FEB, Zaky EA, El-Sayed AB, Elhossieny RM, Zahra SS, Salah Eldin $W$, et al. Assessment of hair aluminum, lead, and mercury in a sample of autistic Egyptian children: environmental risk factors of heavy metals in autism. Behav Neurol. 2015;2015:1-9. https://doi.org/10.1155/2015/545674.

23. Wang $M$, Hossain F, Sulaiman $R$, Ren $X$. Exposure to inorganic arsenic and Lead and autism Spectrum disorder in children : a systematic review and meta-analysis. Chem Res Toxicol. 2019;32(10):1904-19. https://doi.org/10. 1021/acs.chemrestox.9b00134.

24. Rossignol DA, Genuis SJ, Frye RE. Environmental toxicants and autism spectrum disorders: a systematic review. Transl Psychiatry. 2014;4(2):1-23. https://doi.org/10.1038/tp.2014.4.

25. Fido A, Al-Saad S. Toxic trace elements in the hair of children with autism. Autism. 2005;9(3):290-8. https://doi.org/10.1177/1362361305053255.

26. Albizzati A, More L, Di Candia D, Saccani M, Lenti C. Normal concentrations of heavy metals in autistic spectrum disorders. Minerva Pediatr. 2012;64(1):27-31.

27. Adams JB, Holloway CE, George F, Quig D. Analyses of toxic metals and essential minerals in the hair of Arizona children with autism and associated conditions, and their mothers. Biol Trace Elem Res. 2006;110:193-209. https://doi.org/10.1385/BTER:110:3:193.

28. De Palma G, Catalani S, Franco A, Brighenti M, Apostoli P. Lack of correlation between metallic elements analyzed in hair by ICP-MS and autism. J Autism Dev Disord. 2012;42:342-53.

29. Dickerson AS, Rahbar MH, Bakian AV, Bilder DA, Harrington RA, Pettygrove S, et al. Autism spectrum disorder prevalence and associations with air concentrations of lead, mercury, and arsenic. Environ Monit Assess. 2016; 188(7). https://doi.org/10.1007/s10661-016-5405-1.

30. ATSDR (Agency for Toxic Substances and Disease Registry). Toxicological profile for arsenic. Atlanta: U.S. Department of Health and Human Services. Public Health Service; 2007. http://www.atsdr.cdc.gov/toxprofiles/tp2.pdf. Accessed 25 Jan 2018.

31. Kałużna-Czaplińska J, Grys W, Rynkowski J. Neurotoxic factors in the child's environment as a reason for developmental disorders in autism. Nowa Pediatr. 2008;12(3):50-7 (In Polish).

32. IARC (International Agency for Research on Cancer). A review of human carcinogens - arsenic, metals, fibres, and dusts. In: IARC Monographs on the Evaluation of Carcinogenic Risks to Humans, vol. 100C. Lyon: WHO; 2012. p. 41-85. https://monographs.iarc.fr/wp-content/uploads/2018/06/mono100C. pdf. Accessed 25 Jan 2018

33. Bizoń A, Andrzejewska A, Milnerowicz $H$. The role of arsenic compounds in oxidative stress and in the development of diabetes. Environ Med. 2013; 16(3):47-54 (In Polish).

34. Kulik-Kupka K, Koszowska A, Brończyk-Puzoń A, Nowak J, Gwizdek K, Zubelewicz-Szkodzińska B. Arsenic - Poison or medicine? Med Pr. 2016; 67(1):89-96. https://doi.org/10.13075/mp.5893.00322 (In Polish).

35. Adams JB, Audhya T, McDonough-Means S, Rubin RA, Quig D, Geis E, et al. Toxicological status of children with autism vs. Neurotypical children and the association with autism severity. Biol Trace Elem Res. 2012;151(2):17180. https://doi.org/10.1007/s12011-012-9551-1.

36. ATSDR (Agency for Toxic Substances and Disease Registry). Toxicological profile for lead. Atlanta: U.S. Department of Health and Human Services. Public Health Service; 2007. http://www.atsdr.cdc.gov/toxprofiles/tp13.pdf. Accessed 25 Jan 2018.

37. Cairney S, Maruff P, Burns CB, Currie J, Currie BJ. Saccade dysfunction associated with chronic petrol sniffmg and lead encephalopathy. J Neurol Neurosurg Psychiatry. 2004;75:472-6. https://doi.org/10.1136/jnnp.2003. 019406.

38. Gidlow DA. Lead toxicity. Occup Med. 2004;54:76-81. https://doi.org/10. 1093/occmed/kgh019.

39. Ahamed M, Siddiqui MKJ. Environmental lead toxicity and nutritional factors. Clin Nutr. 2007;26:400-8. https://doi.org/10.1016/j.clnu.2007.03.010.

40. Cecil M, Brubaker J, Adler M, Dietrich N, Altaye M, Egelhoff C, et al. Decreased brain volume in adults with childhood lead exposure. PLoS Med. 2008:5(5):112-7.

41. Goodlad JK, Marcus DK, Fulton JJ. Lead and attention-deficit/hyperactivity disorder (ADHD) symptoms:a meta-analysis. Clin Psychol Rev. 2013;33:41725. https://doi.org/10.1016/j.cpr.2013.01.009.

42. Hong SB, Im MH, Kim JW, Park EJ, Shin MS, Kim BN, et al. Environmental lead exposure and attention deficit/hyperactivity disorder symptom 
domains in a community sample of south Korean school-age children. Environ Health Perspect. 2015;123(3):271-6. https://doi.org/10.1289/ehp. 1307420.

43. Almogren A, Shakoor Z, Almomen A, Hasanato RMW. Levels of heavy metal and trace element among children with autism spectrum disorders. Curr Pediatr Res. 2013;17(2):79-83.

44. Geier DA, Kern JK, King PG, Sykes LK, Geier MR. Hair toxic metal concentrations and autism spectrum disorder severity in young children. Int J Environ Res Public Health. 2012;9(12):4486-97. https://doi.org/10.3390/ ijerph9124486.

45. Huang S, Hu H, Sánchez BN, Peterson KE, Ettinger AS, Lamadrid-Figueroa H, Schnaas $L$, et al. Childhood blood lead levels and symptoms of attention deficit hyperactivity disorder (ADHD): a cross-sectional study of Mexican children. Environ Health Perspect. 2016;124(6):868-74. https://doi.org/10. 1289/ehp.1510067.

46. Guney E, Cetin FH, Iseri E. The role of environmental factors in etiology of attention - deficit hyperactivity disorder. ADHD New Dir Diagn Treat. 2015; 2:15-34. https://doi.org/10.5772/61025.

47. Adams J, Howsmon DP, Kruger U, Geis E, Gehn E, Fimbres V, et al. Significant association of urinary toxic metals and autism-related symptomsa nonlinear statistical analysis with cross validation. PLoS One. 2017;12(1). https://doi.org/10.1371/journal.pone.0169526.

48. Parajuli RP, Fujiwara T, Umezaki M, Watanabe C. Association of cord blood levels of lead, arsenic, and zinc with neurodevelopmental indicators in newborns: a birth cohort study in Chitwan Valley, Nepal. Environ Res. 2013; 121:45-51. https://doi.org/10.1016/j.envres.2012.10.010.

49. Fiłon J, Ustymowicz-Farbiszewska J, Karczewski J, Żendzian-Piotrowska M. Analysis of trace element content in hair of autistic children. J Elem. 2017; 22(4):1285-93. https://doi.org/10.5601/jelem.2016.21.4.1355.

50. Luo Y, McCullough LE, Tzeng JY, Darrah T, Vengosh A, Maguire RL, et al. Maternal blood cadmium, lead and arsenic levels, nutrient combinations, and offspring birthweight. BMC Public Health. 2017;17(1):354. https://doi. org/10.1186/s1 2889-017-4225-8.

51. Pater A, Odrowąż-Sypniewska G, Gruszka M. The role of calcium in body function. Przegląd Medycyny Laboratoryjnej. 2005;2(4):13-6 (In Polish).

\section{Publisher's Note}

Springer Nature remains neutral with regard to jurisdictional claims in published maps and institutional affiliations.

Ready to submit your research? Choose BMC and benefit from:

- fast, convenient online submission

- thorough peer review by experienced researchers in your field

- rapid publication on acceptance

- support for research data, including large and complex data types

- gold Open Access which fosters wider collaboration and increased citations

- maximum visibility for your research: over $100 \mathrm{M}$ website views per year

At $\mathrm{BMC}$, research is always in progress.

Learn more biomedcentral.com/submissions 